\title{
Jin, Mikos, Srolovitz, and Stritzker to Chair 2000 MRS Fall Meeting
}

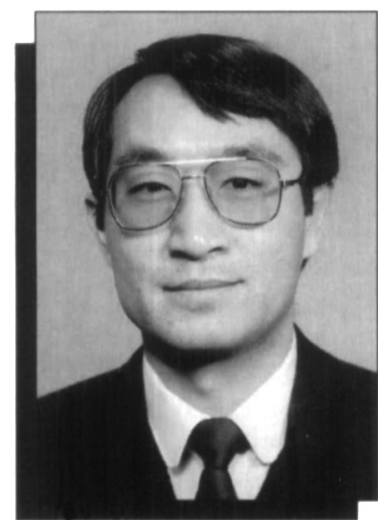

Sungho Jin

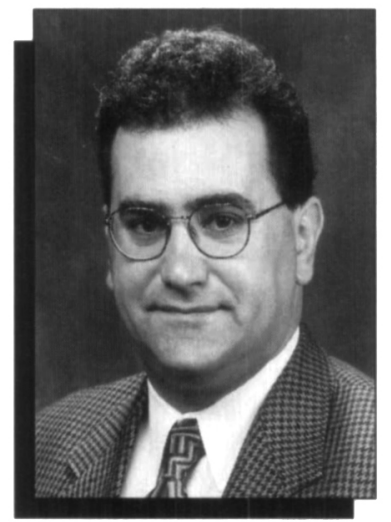

Antonios G. Mikos

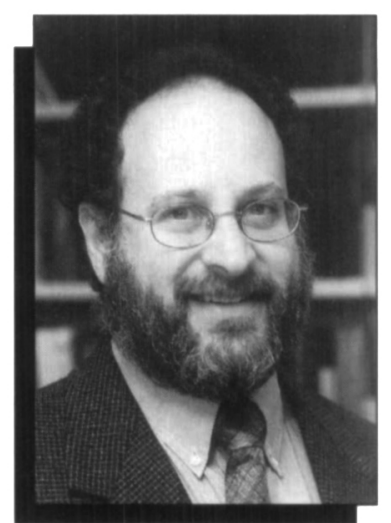

David J. Srolovitz

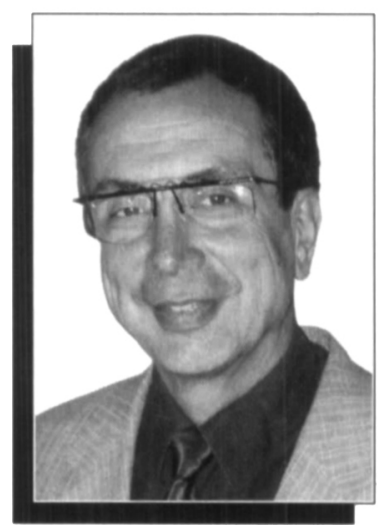

Bernd Stritzker
The 2000 Materials Research Society Fall Meeting in Boston, November 27 to December 1, will be chaired by Sungho Jin (Bell Laboratories, Lucent Technologies), Antonios G. Mikos (Rice University), David J. Srolovitz (Princeton University), and Bernd Stritzker (University of Augsburg, Germany). The meeting's 34 symposia will highlight new advances in the synthesis and application of materials in fields ranging from advanced integrated circuits to biomaterials. Four symposia on biomaterials have been included in order to reflect the recent surge in interest in the subject. Orthopedic/dental, cardiovascular, neurologic biomaterials, and biomaterials for drug delivery will be covered. These symposia will address important issues of synthesis, processing, characterization, and evaluation of biomaterials for medical and pharmaceutical applications.

Many new and developing areas of materials science as well as some wellestablished and popular topics have been included. Several silicon processing symposia will cover areas from dopant-defect interactions, silicides, and dielectrics to interconnects. Thin-film materials and processes will be well represented, featuring magnetoelectronics, polycrystalline films, corrosion and epitaxy of oxides and semiconductors. Symposia on materials processing and devices will present the state-of-the-art in flat-panel displays, wide-bandgap devices, and novel oxidebased devices. Interesting materials such as optoelectronic polymers and thermoelectrics will also be discussed, and MRS will host two new symposia on millimeterwave technology for materials characterization and on direct-write technologies. Two symposia will be dedicated to materials modeling and, for the first time on the West Coast, a symposium on materials education will be held. A symposium on analyzing, predicting, and preventing dis- asters will include many good examples of when materials really matter.

Sungho Jin is technical manager of the Applied Materials and Metallurgy Research Group at Bell Laboratories, Lucent Technologies. His research interests include research and development of magnetic, electronic, and superconducting materials as well as interconnection and packaging materials. He received his $\mathrm{PhD}$ degree in materials science and engineering from the University of CaliforniaBerkeley in 1974. After two years of research at Lawrence Berkeley Laboratory, he joined Bell Laboratories at Murray Hill, New Jersey in 1976.

Jin has published about 200 papers, has given more than 80 invited talks at various materials-related technical meetings, and has 140 U.S. patents issued or pending. He serves as a Principal Editor of the Journal of Materials Research. He also serves as the committee chair of the Electronic Packaging \& Interconnection Materials Committee of the Minerals, Metals \& Materials Society (TMS) and is a council member of the TMS Electronic Magnetic and Photonic Materials Division. He is the recipient of an SRC Outstanding Mentor Award from the Semiconductor Research Corporation, a Fellow of ASM International, and has been elected as a member of the U.S. National Academy of Engineering in 1999.

Antonios G. Mikos is the J.W. Cox Professor of Bioengineering and Chemical Engineering and Director of J.W. Cox Laboratory of Biomedical Engineering at Rice University. He received his DiplEng degree (1983) from the Aristotle University of Thessaloniki, Greece, and his PhD degree (1988) from Purdue University, both in chemical engineering. He joined the Rice faculty in 1992 as the T.N. Law Assistant Professor and was promoted to Associate Professor in 1996 and to Pro- fessor in 1999. Mikos' research contributions have been in the synthesis, processing, and evaluation of new biomaterials for tissue engineering, scaffolds for threedimensional cell culture, conduits for guided tissue regeneration, substrates for targeted cell adhesion, carriers for controlled drug delivery, and nonviral vectors for gene therapy. His research has led to the development of novel orthopedic, cardiovascular, neurologic, and ophthalmologic biomaterials.

Mikos was elected Fellow of the American Institute for Medical and Biological Engineering in 1999. He has been recognized by various awards including the 1998 Young Investigator Research Achievement Award of the Controlled Release Society, the 1996 Outstanding Young Investigator Award of the Materials Research Society, the 1994 Whitaker Young Investigator Award of the Biomedical Engineering Society, and the 1991 Victor K. LaMer Award of the American Chemical Society. He was the recipient of a FIRST Award of the National Institutes of Health in 1996. Mikos is Founding Member of the Bioengineering Department at Rice University (1997). He is Founding Editor of the journal Tissue Engineering and a member of the editorial boards of various journals in biomaterials. He is also a Founding Member (1996) of the Tissue Engineering Society, where he served as vice president in 1998.

David J. Srolovitz is a Professor at the Princeton Materials Institute and Department of Mechanical and Aerospace Engineering at Princeton University. He received his $\mathrm{PhD}$ degree in Materials Science from the University of Pennsylvania in 1981. He then spent two years at Exxon's Corporate Research Science Laboratory, three years in the Theoretical Division of Los Alamos National Laboratory and 12 years at the University of 
Michigan, where he was the Campbell Professor of Materials Science and Engineering. His research interests include the deposition of thin films, microstructure/morphology evolution, the structure and properties of defects, and deformation. He addresses these areas using atomistic, electronic, and continuum scale computer simulations and analytical methods.

Srolovitz is co-editor-in-chief of the journal Interface Science and on the executive board of the journal Modeling and Simulation in Materials Science \& Engineering. Srolovitz is a Fellow of ASM International and the Institute of Physics, and the recipient of Outstanding Paper Awards from Acta Materialia, NASA, and the AIChE, the ASM Research Silver Medal, awards from the Exxon and Alcoa Foundations and was the Michael Visiting Fellow of the Weizmann Institute of Science. He has published over 200 research papers, edited four books, and holds two patents.

Bernd Stritzker is a full professor for experimental physics at the University of Augsburg in Germany. He received his diploma in physics from the University in Karlsuhe in 1970 before he joined the staff of the Research Center in Juelich (former KFA). In 1973 he received his $\mathrm{PhD}$ in physics at the University Karlsruhe. $\mathrm{He}$ stayed in various positions at KFA, interrupted by an 18-month stay in the Solid State Division at Oak Ridge National Laboratory in 1979. Since 1980 he also served as a lecturer at the University of Cologne. After several other offers he took the chair at the University of Augsburg in 1990, where a new physics department had been founded. His current interests are in the area of near-surface modifications by ion, plasma-, and laser-techniques, concentrating on ferroelectric-, HTS-, diamondand $\mathrm{SiC}$-thin films.

He served in several functions in the following societies: elected councillor of the German Physical Society (DPG); symposia organizer, member of the executive committee and 1992 president of the European-MRS; member of the commission on finance of the International Union of Materials Research Societies; symposium organizer for MRS; member of the MRS-membership committee; and member of the advisory review board of the Journal of Materials Research. He was a member of the scientific advisory committees of Hahn-Meitner-Institut Berlin (six years) and Research Center Rossendorf (10 years).

He holds five patents and authored and co-authored more than 250 scientific papers in the field of thin films and their modification by ion-, plasma- and laserbeams. He was on the editorial board of several journals, wrote several review papers, and edited several conference proceedings.

\section{THE SŌMIYA AWARD FOR INTERNATIONAL COOPERATION}

\section{Call for Nominations}

The Sōmiya Award for International Cooperation, endowed by the International Union of Materials Research Societies, is named in honor of Shigeyuki Sōmiya, formerly of the Tokyo Institute of Technology and later of the Teikyo University. Sōmiya has been a champion of cooperation between Japan, the United States, and Europe.

\section{The following criteria will be used by the Selection Committee:}

1. The team to be honored must have collaborated across at least two continents (e.g., N. America, Europe, Asia, Australia) for some time during the last decade.

2. The collaborative work must have been of the highest quality and well recognized by the community.

3. Other things being equal, the impact on technology or society will be a major factor.

The award recipient will be required to present a talk at the IUMRS Strasbourg meeting in May 2000. The award will consist of an art object and an honorarium.

Nomination Deadline: March 15, 2000.

Submit nominations to Prof. R.P.H. Chang, Northwestern University, MLSF 2013, 2225 N. Campus Drive, Evanston, IL 60208, on the forms available on the website at www.iumrs.org, or upon request by fax to Chair, IUMRS Awards Committee: 847-491-4181.

The Selection Committee consists of R.P.H. Chang, Paul Siffert, Rustum Roy, and S. Sōmiya, the IUMRS Awards Commission. 